\title{
29. GEOCHEMISTRY OF NAURU BASIN BASALTS FROM THE LOWER PORTION OF HOLE 462A, DEEP SEA DRILLING PROJECT LEG 61 ${ }^{1}$
}

\author{
Karl E. Seifert, Department of Earth Sciences, Iowa State University, Ames, Iowa
}

\begin{abstract}
Atomic-absorption spectrophotometry and instrumental neutron activation analysis were used to determine concentrations of $\mathrm{SiO}_{2}, \mathrm{Al}_{2} \mathrm{O}_{3}, \mathrm{FeO}_{\mathrm{t}}, \mathrm{MgO}, \mathrm{CaO}, \mathrm{Na}_{2} \mathrm{O}, \mathrm{K}_{2} \mathrm{O}, \mathrm{MnO}, \mathrm{La}, \mathrm{Ce}, \mathrm{Sm}, \mathrm{Eu}, \mathrm{Tb}, \mathrm{Yb}, \mathrm{Lu}, \mathrm{Sc}, \mathrm{Co}, \mathrm{Cr}, \mathrm{Th}, \mathrm{Hf}$, and Ta for 14 basalt samples from the lower portion of Hole $462 \mathrm{~A}$ in the Nauru Basin. The basalts are similar to normal midocean ridge basalt (MORB) for the elements analyzed, and light rare-earth elements (LREE) are depleted relative to heavy rare-earth elements (HREE). Two samples are extensively altered to smectites and show significant reductions in $\mathrm{Al}_{2} \mathrm{O}_{3}, \mathrm{CaO}, \mathrm{MnO}, \mathrm{Na}_{2} \mathrm{O}, \mathrm{REE}, \mathrm{Sc}, \mathrm{Co}$, and $\mathrm{Hf}$ and gains in $\mathrm{MgO}$ and $\mathrm{FeO}_{\mathrm{t}}$ relative to unaltered samples. The increase in $\mathrm{MgO}$ and decrease in $\mathrm{CaO}$ indicate that alteration was caused by hydrothermal solutions.
\end{abstract}

\section{INTRODUCTION}

Drilling at Site 462 , Hole $462 \mathrm{~A}\left(07^{\circ} 15^{\prime} \mathrm{N}, 165^{\circ}\right.$ $02^{\prime} \mathrm{E}$ ), penetrated over 500 meters of basaltic flows and sills and sediments in the Nauru Basin, west central Pacific Ocean. The thick volcanic sequence appears to represent a mid-Cretaceous intraplate plateau sequence of tholeiitic basalts structurally similar to the Caribbean Sea floor. The lower portion of Hole 462A, Cores 75 through 90, were drilled on the extension of Leg 61 . These lower basalts have been analyzed in this study.

The Nauru Basin is bounded to the east by the Marshall Island atolls and to the west by the Caroline Islands. The basin is regarded as having formed at a fast-spreading Pacific plate boundary about 145-155 m.y. ago (Late Jurassic), and Site 462 was drilled in the Jurassic magnetically quiet zone (Larson, 1976) on magnetic Anomaly $M-26$. The magmas giving rise to the volcanic complex apparently penetrated Jurassic basement without significantly disturbing the well-defined lineation pattern observed in the Nauru Basin. The drill holes closest to Site 462 are in the Marshall Islands, the Bikini hole (Emery et al., 1954) and the Eniwetok hole (Ladd et al., 1953).

The Nauru Basin represents a region of buoyant ocean floor that does not fit the normal age-versusdepth curve (Sclater et al., 1971). The Pacific Ocean contains many exceptions to the curve (Winterer, 1976), although most have a volcanic topography. The region that appears most similar to the Nauru Basin is the Caribbean Basin. The Caribbean crust is abnormally thick (Officer et al., 1959; Edgar et al., 1971), largely because of the intrusion of a great thickness of sills in the Late Cretaceous (Burke et al., 1978). However, intrusion of sills in the Caribbean is regarded as responsible for the lack of magnetic anomalies in that region (Fox and Heezen, 1975), and in this respect the Carib-

\footnotetext{
${ }^{1}$ Initial Reports of the Deep Sea Drilling Project, Volume 61
}

bean Basin stands in contrast to the Nauru Basin with its well-defined magnetic anomalies. The extent to which heating of oceanic lithosphere might contribute to the buoyancy of these regions, in the manner suggested by Crough (1978) for hot-spot swells, is discussed by Schlanger and Premoli Silva (this volume).

\section{STUDY TECHNIQUES}

Basalts from the lower part of Hole $462 \mathrm{~A}$ basalts have been analyzed for $\mathrm{Na}_{2} \mathrm{O}, \mathrm{FeO}_{t}$, for trace elements by an instrumental neutron-activation analysis (INAA) technique described by Jacobs et al. (1977), and for major elements by atomic absorption spectrophotometry (AA). Major element oxides $\mathrm{FeO}_{t}$ and $\mathrm{Na}_{2} \mathrm{O}$ and trace elements $\mathrm{La}, \mathrm{Ce}, \mathrm{Sm}, \mathrm{Eu}, \mathrm{Tb}, \mathrm{Yb}, \mathrm{Lu}, \mathrm{Sc}, \mathrm{Co}, \mathrm{Cr}, \mathrm{Th}, \mathrm{Hf}$, and $\mathrm{Ta}$ were determined by INAA. $\mathrm{SiO}_{2}, \mathrm{Al}_{2} \mathrm{O}_{3}, \mathrm{FeO}_{t}, \mathrm{MgO}, \mathrm{CaO}, \mathrm{Na}_{2} \mathrm{O}$, $\mathrm{K}_{2} \mathrm{O}$, and $\mathrm{MnO}$ were determined by AA. Reference standards, run simultaneously with Nauru Basin basalts, include USGA standards BCR-1, BHVO-1, AGV-1, and GSP-1 and NASA standard Knippa. Rare earth elements (REE) are plotted relative to chondrites using chondrite values of Haskin et al. (1968).

\section{DATA}

Geochemical data given in Table 1 represent a downhole continuation of data given by Batiza (this volume). Batiza presents data for Hole 462 and the upper portion of Hole 462A (down through Core 74). These data continue from Core 74 to the bottom of Hole 462A, and include Cores 75 through 90, the portion of Hole $462 \mathrm{~A}$ drilled on the extension of Leg 61 by the Leg 62 crew.

The geochemistry of basalt Cores 75 through 79 is very similar to that of basalts from Cores 74 upward, and appears to represent a continuation of those basalts. From Core 80 down, however, the geochemistry is somewhat different, marked most noticeably by higher concentrations of REE, $\mathrm{FeO}_{\mathrm{t}}$, and $\mathrm{Hf}$, and less abundant $\mathrm{MgO}$ and $\mathrm{Cr}$. Two samples (462A-88-2, 100$102 \mathrm{~cm}$ and $462 \mathrm{~A}-88-3,9-11 \mathrm{~cm}$ ) are badly altered to smectites, and their geochemistry is distinct from that of either the upper basalts (Cores 75-79) or the lower basalts (Cores 80-90).

All basalts studied are LREE-depleted relative to HREE (Fig. 1), although the two altered samples show 
Table 1. Geochemistry of Nauru Basin basalts from the lower portion of DSDP Hole 462A. (Oxides are in wt. \% and elements in ppm.)

\begin{tabular}{|c|c|c|c|c|c|c|c|c|c|c|c|c|c|c|}
\hline \multirow[b]{2}{*}{$\begin{array}{l}\text { Core-Sec., } \\
\text { Interval }(\mathrm{cm})\end{array}$} & \multicolumn{3}{|c|}{ Upper Basalts } & \multicolumn{9}{|c|}{ Lower Basalts } & \multicolumn{2}{|c|}{ Altered Basalts } \\
\hline & $\begin{array}{c}76-1 \\
41-43\end{array}$ & $\begin{array}{c}79-3 \\
79-81\end{array}$ & $\begin{array}{c}79-5 \\
127-130\end{array}$ & $\begin{array}{c}80-3 \\
58-61\end{array}$ & $\begin{array}{c}80-3 \\
145-148\end{array}$ & $\begin{array}{c}80-4 \\
36-39\end{array}$ & $\begin{array}{l}81-3 \\
63-65\end{array}$ & $\begin{array}{c}84-4 \\
56-58\end{array}$ & $\begin{array}{c}87-1 \\
105-107\end{array}$ & $\begin{array}{c}88-2 \\
95-97\end{array}$ & $\begin{array}{c}89-3 \\
125-127\end{array}$ & $\begin{array}{l}90-4, \\
63-65\end{array}$ & $\begin{array}{c}88-2, \\
100-102\end{array}$ & $\begin{array}{l}88-3 \\
9-11\end{array}$ \\
\hline $\mathrm{SiO}_{2}$ & 49.78 & 49.22 & 49.35 & 49.19 & 48.70 & 48.57 & 50.26 & 49.95 & 50.25 & 48.95 & 49.23 & 50.32 & 49.32 & 49.35 \\
\hline $\mathrm{Al}_{2} \mathrm{O}_{3}$ & 13.74 & 13.86 & 13.81 & 13.63 & 13.80 & 13.89 & 14.34 & 13.68 & 13.69 & 13.77 & 14.71 & 14.05 & 12.13 & 12.27 \\
\hline $\mathrm{FeO}_{\mathrm{t}}$ & 11.67 & 11.67 & 11.57 & 13.13 & 12.34 & 12.33 & 12.45 & 12.65 & 12.73 & 12.72 & 13.39 & 11.71 & 13.41 & 13.45 \\
\hline $\mathrm{MgO}$ & 7.76 & 7.71 & 7.81 & 6.79 & 6.44 & 6.71 & 7.03 & 6.86 & 7.26 & 6.95 & 7.03 & 6.98 & 9.68 & 8.78 \\
\hline $\mathrm{CaO}$ & 11.83 & 12.31 & 12.20 & 11.48 & 11.27 & 11.09 & 11.32 & 11.18 & 11.13 & 11.18 & 11.71 & 11.36 & 10.09 & 10.37 \\
\hline $\mathrm{Na}_{2} \mathrm{O}$ & 2.11 & 2.08 & 2.15 & 2.30 & 2.26 & 2.29 & 2.18 & 2.30 & 2.16 & 2.25 & 2.23 & 2.45 & 1.78 & 1.81 \\
\hline $\mathrm{K}_{2} \mathrm{O}$ & 0.06 & 0.01 & 0.02 & 0.03 & 0.06 & 0.04 & 0.01 & 0.06 & 0.05 & 0.07 & 0.03 & 0.08 & 0.03 & 0.03 \\
\hline $\mathrm{MnO}$ & 0.19 & 0.20 & 0.21 & 0.22 & 0.20 & 0.21 & 0.21 & 0.21 & 0.21 & 0.21 & 0.25 & 0.19 & 0.14 & 0.15 \\
\hline $\mathrm{La}$ & 2.83 & 2.66 & 2.73 & 3.40 & 3.41 & 3.38 & 3.41 & 3.45 & 3.12 & 3.29 & 3.24 & 3.47 & 2.70 & 2.10 \\
\hline $\mathrm{Ce}$ & 8.12 & 8.31 & 8.49 & 10.2 & 9.70 & 9.38 & 9.45 & 10.2 & 9.19 & 10.5 & 9.94 & 10.7 & 6.84 & 5.61 \\
\hline $\mathrm{Sm}$ & 2.25 & 2.26 & 2.25 & 2.67 & 2.81 & 2.74 & 2.84 & 2.94 & 2.44 & 2.75 & 2.82 & 2.89 & 1.50 & 1.56 \\
\hline $\mathrm{Eu}$ & 0.86 & 0.92 & 0.88 & 1.06 & 1.02 & 0.99 & 1.01 & 1.06 & 0.95 & 1.03 & 0.99 & 1.09 & 0.63 & 0.59 \\
\hline $\mathrm{Tb}$ & 0.59 & 0.56 & 0.62 & 0.73 & 0.67 & 0.68 & 0.71 & 0.71 & 0.79 & 0.66 & 0.76 & 0.72 & 0.41 & 0.43 \\
\hline $\mathrm{Yb}$ & 2.24 & 2.19 & 2.43 & 2.99 & 2.95 & 2.90 & 2.99 & 3.07 & 2.66 & 2.86 & 3.00 & 2.80 & 1.65 & 1.76 \\
\hline Lu & 0.34 & 0.37 & 0.36 & 0.47 & 0.43 & 0.42 & 0.44 & 0.46 & 0.42 & 0.42 & 0.47 & 0.45 & 0.26 & 0.26 \\
\hline Sc & 47.3 & 48.7 & 48.3 & 50.0 & 47.3 & 48.1 & 47.9 & 49.1 & 49.8 & 49.1 & 50.7 & 51.6 & 42.6 & 42.7 \\
\hline Co & 49.4 & 50.4 & 50.2 & 51.1 & 48.4 & 48.6 & 48.7 & 50.4 & 50.4 & 49.9 & 51.3 & 52.1 & 39.0 & 39.6 \\
\hline $\mathrm{Cr}$ & 313 & 325 & 325 & 194 & 181 & 187 & 180 & 180 & 207 & 186 & 200 & 197 & 212 & 205 \\
\hline Th & 0.12 & - & 0.25 & 0.27 & 0.22 & 0.21 & 0.14 & 0.23 & 0.18 & 0.21 & 0.16 & - & - & 0.09 \\
\hline $\mathrm{Hf}$ & 1.70 & 1.71 & 1.77 & 1.02 & 2.01 & 2.05 & 2.10 & 2.23 & 2.04 & 2.04 & 2.09 & 2.21 & 1.02 & 1.14 \\
\hline $\mathrm{Ta}$ & 0.17 & 0.21 & 0.16 & 0.26 & 0.19 & 0.21 & 0.18 & 0.27 & 0.27 & 0.20 & 0.20 & 0.24 & - & - \\
\hline
\end{tabular}

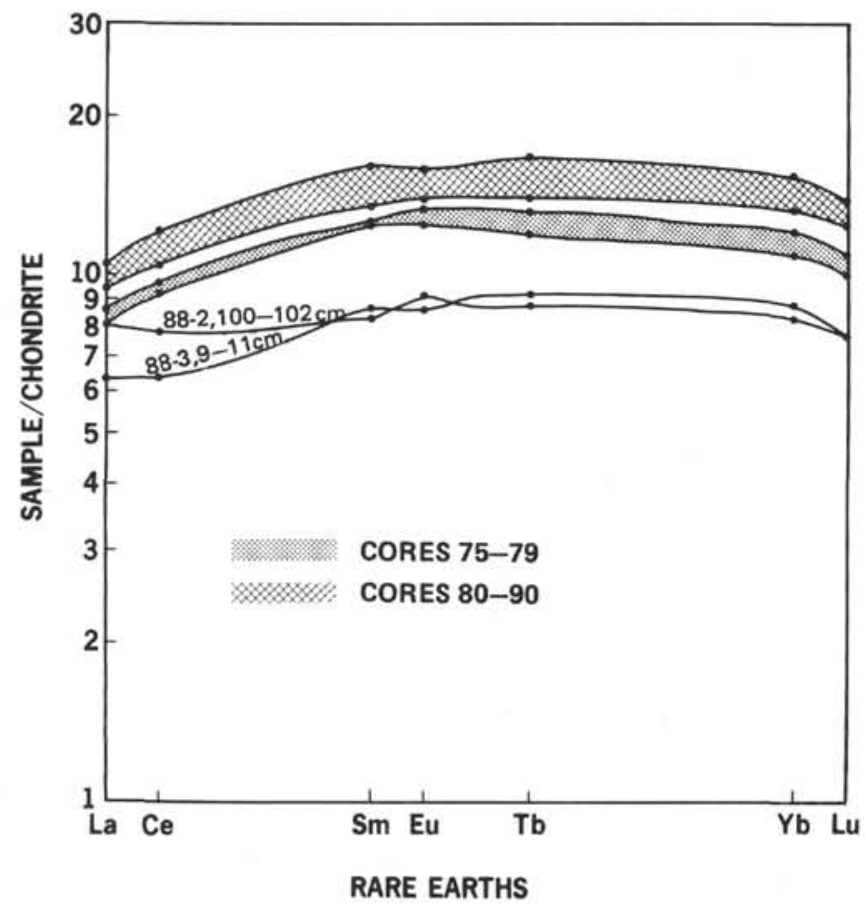

Figure 1. Normalized rare-earth element abundances of basalts from the lower portion of Hole $462 \mathrm{~A}$. These basalts are divided into three groups: the lower basalts (Cores 80-90), the upper basalts (Cores 75-79), and two altered basalts with lower total REE but higher LREE/HREE ratios.

less LREE depletion. Plots of selected elements show three distinct groups: (a) the upper basalts, (b) the lower basalts, and (c) the two altered basalts (Figs. 2-4). Separation of upper and lower basalts is best observed in the plot of $\mathrm{Cr}$ versus $\mathrm{Hf}$ (Fig. 2). The upper basalts are much richer in $\mathrm{Cr}$ than lower basalts, and have relatively lower $\mathrm{Hf}$ values. Both badly altered samples

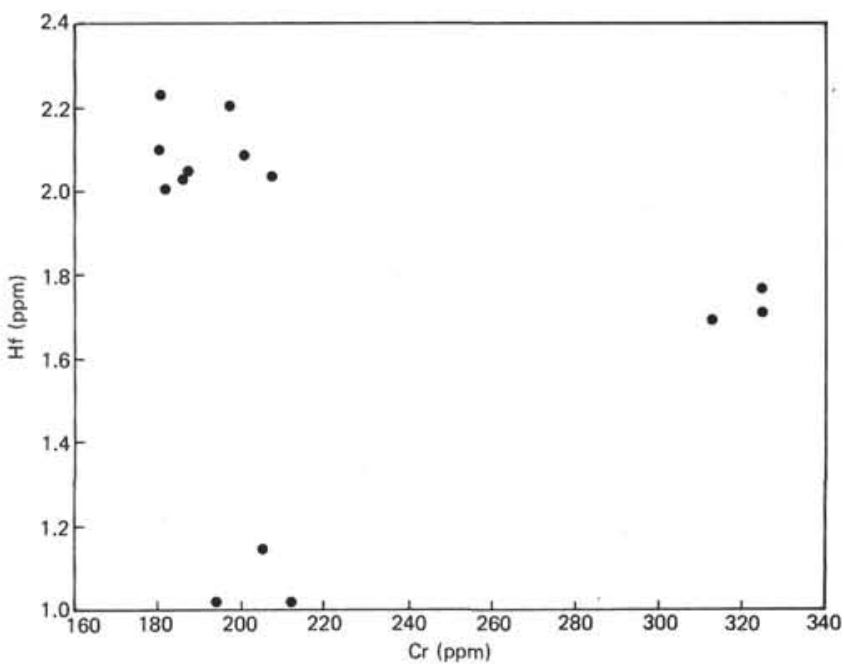

Figure 2. Plot of $\mathrm{Hf}$ versus $\mathrm{Cr}$, showing the much greater abundance of $\mathrm{Cr}$ in the upper basalts ( $>300 \mathrm{ppm}$ ) compared with the lower basalts $(<220 \mathrm{ppm})$. The altered basalts have both very low $\mathrm{Cr}$ and Hf contents.

have very low $\mathrm{Hf}$ values, as does one sample of lower basalt $(462 \mathrm{~A}-80-3,58-61 \mathrm{~cm})$ in which alteration is not obvious. Figure 3 shows that upper basalts have a higher $\mathrm{MgO} /\left(\mathrm{MgO}+\mathrm{FeO}_{\mathrm{t}}\right)$ ratio than lower basalts, and that alteration has noticeably increased the $\mathrm{MgO} /(\mathrm{MgO}+$ $\mathrm{FeO}_{t}$ ) ratio in the two altered lower basalts. On the $\mathrm{Yb}$ versus-Sm plot, the sample from Core 87 is intermediate between upper and lower basalts, although all samples still form a linear plot (Fig. 4).

\section{DISCUSSION}

Basalts from the lower portion of Hole 462A have the geochemical characteristics of normal (N-type) MORB (Sun et al., 1979). Chondrite-normalized REE plots 


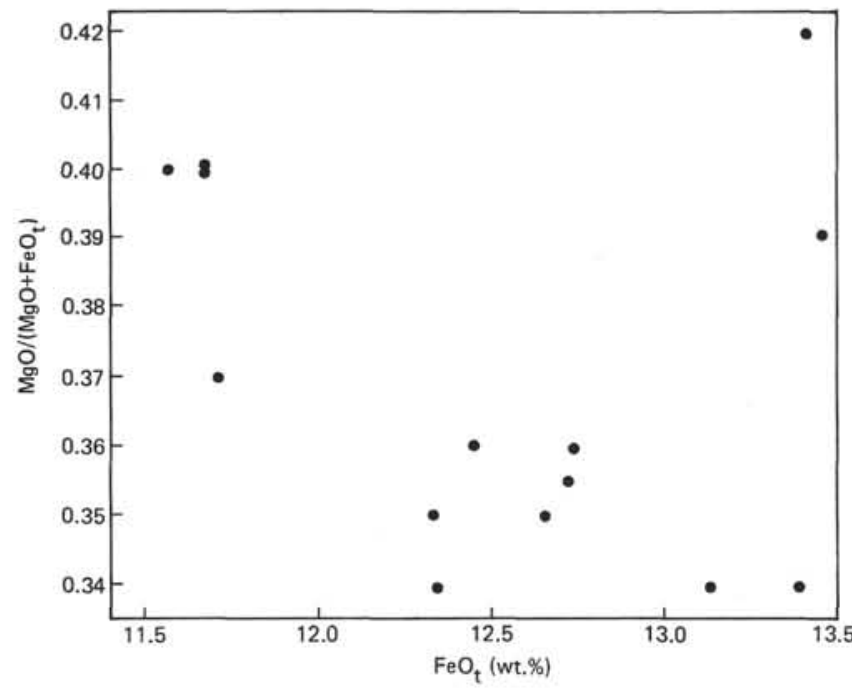

Figure 3. Plot of $\mathrm{MgO} /\left(\mathrm{MgO}+\mathrm{FeO}_{t}\right)$ versus $\mathrm{FeO}_{t}$, showing the higher $\mathrm{MgO} /\left(\mathrm{MgO}+\mathrm{FeO}_{\mathrm{t}}\right)$ ratio in upper and altered basalts relative to lower basalts.

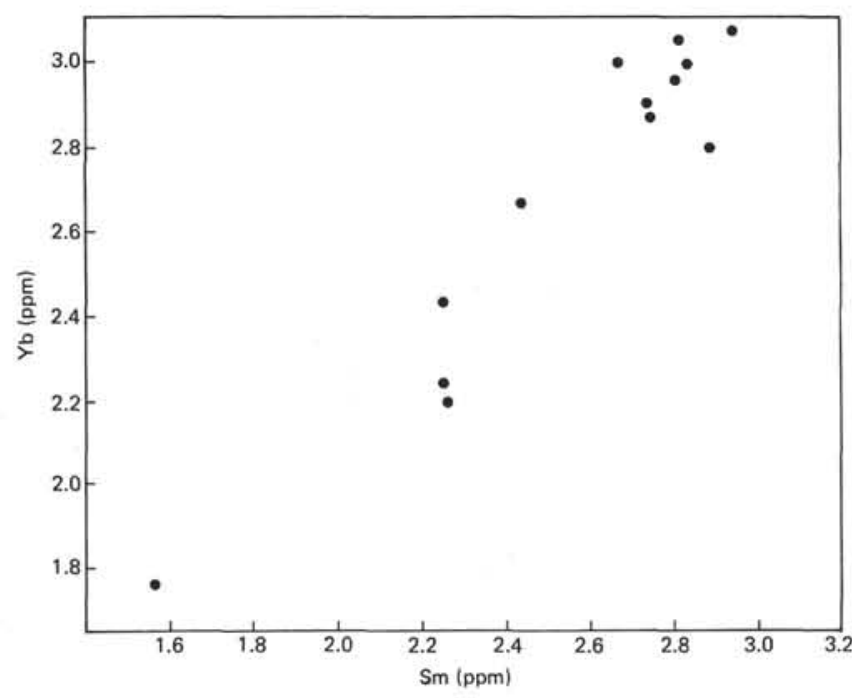

Figure 4. Plot of $\mathrm{Yb}$ versus $\mathrm{Sm}$, exhibiting the greater abundance of $\mathrm{Yb}(>2.6 \mathrm{ppm})$ and $\mathrm{Sm}(>2.4 \mathrm{ppm})$ in the lower basalts compared with the upper basalts. The altered basalts have very low concentrations of $\mathrm{Yb}(<1.8 \mathrm{ppm})$ and $\mathrm{Sm}(<1.6 \mathrm{ppm})$, and yet lie on a straight line through the lower and upper basalt values.

(Fig. 1) all show the LREE to HREE depletion typical of normal MORB. These basalts are interpreted as being derived from a previously depleted mantle source, and are found in all oceans. Both the transitional (T-type) and plume (P-type) MORB are more enriched in LREE relative to HREE (Frey et al., 1974; Schilling and NoeNygaard, 1974).

The geochemical differences in oceanic basalts have been variously explained as resulting from: different degrees of partial melting; a heterogeneous mantle; magmatic differentiation; or secondary alteration. In basalts from the lower portion of Hole $462 \mathrm{~A}$, the two groups of basalts can be distinguished by their contents of $\mathrm{MgO}, \mathrm{Cr}, \mathrm{Hf}$, and total REE. The higher
$\mathrm{MgO} /\left(\mathrm{MgO}+\mathrm{FeO}_{t}\right)$ and $\mathrm{Cr}$ contents of upper basalts relative to higher $\mathrm{Hf}$ and total REE contents in lower basalts is perhaps best explained by differences in degree of magmatic differentiation, since the basalts have similar contents of $\mathrm{Co}$ and $\mathrm{Sc}$ and similar $\mathrm{Hf} / \mathrm{Ta}$ ratios. If the difference between the upper basalts (Cores 75-79) and lower limits (Cores 80-90) in this study is explained as part of a series undergoing magmatic differentiation, the lower basalts must be regarded as more differentiated, and thus more recent, than the upper basalts. However, all basalts from the lower portion of Hole $462 \mathrm{~A}$ are interpreted to be flows (Batiza et al., "Summary of Petrological and Geochemical studies of Leg 61 Basalts,' this volume).

Samples 462A-88-2, 100-102 cm and 462A-88-3, 9-11 $\mathrm{cm}$ both exhibit considerable alteration, and X-ray diffraction analysis indicates broad smectite peaks. The two altered samples have significantly reduced $\mathrm{CaO}$, $\mathrm{Al}_{2} \mathrm{O}_{3}, \mathrm{Na}_{2} \mathrm{O}, \mathrm{MnO}, \mathrm{REE}, \mathrm{Sc}, \mathrm{Co}$, and $\mathrm{Hf}$ contents relative to unaltered samples. $\mathrm{MgO}$ and $\mathrm{FeO}_{\mathrm{t}}$ contents appear to have increased. The increase in $\mathrm{MgO}$ concentration and decrease in $\mathrm{CaO}$ concentration indicates high-temperature hydrothermal alteration, as defined by several experimental studies, such as that by Seyfried and Bischoff (1979). The LREE/HREE ratio has also increased in the two altered basalts, and may indicate enrichment in LREE, as observed by Ludden and Thompson (1979) and several others. The low value of Hf for Sample 462A-80-3, 58-61 cm places that sample with the two altered samples on the Cr-versus-Hf plot, and may also be due to alteration. Sample 462-A-87-1, 105-107 cm occupies an intermediate position on the $\mathrm{Yb}$-versus-Sm plot; this may also be an alteration effect.

\section{ACKNOWLEDGMENTS}

I am indebted to Dr. Larry A. Haskin for allowing the samples to be analyzed on his equipment at Washington University. The use of unpublished data on Leg 61 basalts by Dr. Rodey Batiza is also appreciated. This paper has been improved considerably by reviews from Drs. Marilyn Lindstrom and John Green.

\section{REFERENCES}

Burke, K., Fox, P. J., and Sengor, A. M. C., 1978. Buoyant ocean floor and the evolution of the Caribbean. J. Geophys. Res., 83:3949-3954.

Crough, S. T., 1978. Thermal origin of mid-plate hot-spot swells. Geophys. J. Roy. Astrophys. Soc., 55:451-469.

Edgar, N. T., Ewing, J. I., and Hennion, J., 1971. Seismic refraction and reflection in Caribbean Sea. Am. Assoc. Petrol. Geol. Bull., 55:833-870.

Emery, K. O., Tracy, J. I., and Ladd, H. S., 1954. Geology of Bikini and Nearby Atolls. U.S. Geol. Sur. Prof. Paper 260A.

Fox, P. J., and Heezen, B. C., 1975. Geology of the Caribbean crust. In Nairn, A. E. M., and Stehli, F. G. (Eds.), The Ocean Basins and Margins (Vol. 3), The Gulf of Mexico and the Caribbean: New York (Plenum Press).

Frey, F. A., Bryan, W. B., and Thompson, G., 1974. Atlantic Ocean floor: Geochemistry and petrology of basalts from Legs 2 and 3 of the Deep Sea Drilling Project. J. Geophys. Res., 79:5507-5527.

Haskin, L. A., Haskin, M. A., Frey, F. A., et al., 1968. Relative and absolute terrestrial abundances of the rare earths. In Ahrens, C. H. (Ed.), Origin and Distribution of the Elements: New York (Pergamon Press).

Jacobs, J. W., Korotev, R. L., Blanchard, D. P., et al., 1977. A welltested procedure for instrumental neutron activation analysis of silicate rocks and minerals. J. Radioanal. Chem., 40:93-114. 
Ladd, H. S., Ingerson, E., Townsend, R. C., Russell, M., and Stephenson, H. K., 1953. Drilling on Eniwetok atolls, Marshall Islands. Am. Assoc. Petrol. Geol. Bull., 37:2557-2580.

Larson, R. L., 1976. Late Jurassic and Early Cretaceous evolution of the western central Pacific ocean. J. Geomag. Geoelectr., 28:219-236.

Ludden, J. N., and Thompson, G., 1979. An evaluation of the behavior of the rare earth elements during the weathering of seafloor basalt. Earth Planet. Sci. Lett., 43:85-92.

Officer, C., Ewing, J., Hennion, J., Harkinder, D., and Miller, D., 1959. Geophysical investigations in the eastern Caribbean-summary of the 1955 and 1956 cruises. In Ahrens, C. H., Press, F., Rankama, K., and Runcorn, S. K. (Eds.), Physics and Chemistry of the Earth (Vol. 3): New York (McGraw Hill).
Schilling, J.-G., and Noe-Nygaard, A., 1974. Faeroe-Iceland plume. Rare-earth evidence. Earth Planet. Sci. Lett., 24:1-14.

Sclater, J. G., Anderson, R. N., and Bell, M. L., 1971. Elevation of ridges and evolution of the central eastern Pacific. J. Geophys. Res., 76:7888-7915.

Seyfried, W. E., and Bischoff, J. L., 1979. Low temperature basalt alteration by seawater: An experimental study at $70^{\circ} \mathrm{C}$ and $150^{\circ} \mathrm{C}$. Geochim. Cosmochim. Acta, 43:1937-1947.

Sun, S.-S., Nesbitt, R. W., and Sharaskin, A., 1979. Geochemical characteristics of mid-ocean ridge basalts. Earth Planet. Sci. Lett., 44:119-138.

Winterer, E. L., 1976. Anomalies in the tectonic evolution of the Pacific. In Sutton, G. H., Manghnani, M. H., Moberly, R., and McAfee, E. U. (Eds.), The Geophysics of the Pacific Ocean Basin and Its Margin: Washington (Am. Geophys. Union). 